Article

\title{
Improving Contagion and Horizontal Transmission of Entomopathogenic Fungi by the White-Spotted Longicorn Beetle, Anoplophora malasiaca, with Help of Contact Sex Pheromone
}

\author{
Nao Fujiwara-Tsujii (1D) and Hiroe Yasui * \\ Chemical Ecology Group, Central Region Agricultural Research Center, NARO, Tsukuba, Ibaraki 305-8666, Japan; \\ naoki99@affrc.go.jp \\ * Correspondence: yasui@affrc.go.jp
}

check for updates

Citation: Fujiwara-Tsujii, N.; Yasui, H. Improving Contagion and Horizontal Transmission of Entomopathogenic Fungi by the White-Spotted Longicorn Beetle, Anoplophora malasiaca, with Help of Contact Sex Pheromone. Insects 2021, 12, 383. https://doi.org/10.3390/ insects 12050383

Academic Editor: Jørgen Eilenberg

Received: 5 March 2021

Accepted: 21 April 2021

Published: 26 April 2021

Publisher's Note: MDPI stays neutral with regard to jurisdictional claims in published maps and institutional affiliations.

Copyright: (c) 2021 by the authors. Licensee MDPI, Basel, Switzerland. This article is an open access article distributed under the terms and conditions of the Creative Commons Attribution (CC BY) license (https:/ / creativecommons.org/licenses/by/ $4.0 /)$.
Simple Summary: The white-spotted longicorn beetle, Anoplophora malasiaca, is one of the most destructive pests of many fruits and street trees. Effective controls are needed because the effect of marketed insecticides is limited. Entomopathogenic fungi offer a solution, combination with the beetles' contact sex pheromone. The surface of the female body is covered with contact sex pheromone, which we extracted. Males held onto a glass model coated with female extract for $5 \mathrm{~h}$, but males held onto one without extract for $<0.3 \mathrm{~h}$. Males that held onto coated model, attached to fabric impregnated with an entomopathogenic fungus, Beauveria brongniartii, picked up significant fungi. The fungi were then transferred to females during mating. Our results indicate that a combination of contact pheromone with a pathogen could improve entomopathogenic infection of both male and female beetles.

Abstract: The white-spotted longicorn beetle, Anoplophora malasiaca, is one of the most destructive pests of horticultural crops and street trees. Effective controls are needed because the effect of marketed insecticides is limited. Entomopathogenic fungi offer a solution, and improving the rate of infection would be a breakthrough in this beetle's control. The combination of pathogenic fungi and the beetle's contact sex pheromone was suggested. The surface of the female body is covered with contact sex pheromone, which elicit male mating behavior. To develop a method for the practical control of this beetle, we evaluated the arrestant activity of female extract containing contact pheromone coated on a black glass model. Males presented with a coated model held on for $5 \mathrm{~h}$ (mean) during an 8-h experiment. In contrast, males presented with a control model held on for $<0.3 \mathrm{~h}$. Males that held onto coated models attached to fabric impregnated with conidia of the fungus Beauveria brongniartii picked up much conidia, which they then passed on to females during mating.

Keywords: arrestant; Biolisa Kamikiri SLIM; microbial insecticide; mating; infection; control

\section{Introduction}

The white-spotted longicorn beetle, Anoplophora malasiaca (Thomson) (Coleoptera: Cerambycidae), has a very wide range of host plants exceeding 100 species [1]. It is one of the most destructive pests of horticultural crops and street trees including citrus, blueberry, plane tree, maple, and willow [2,3]. This species is distributed in Japan [3] and effective controls are needed because the effect of marketed chemical insecticides is limited. Microbial insecticides offer a solution [4-10]. Compared to chemical insecticides, entomopathogenic ones pose minimal risk to nontarget organisms and are environmentally friendly [11]. Studies performed with fabric bands impregnated with conidia of entomopathogenic fungi are reported [8-10]. In Japan, non-woven fabric band impregnated with conidia of an entomopathogenic fungus, Beauveria brongniartii, named "Biolisa Kamikiri SLIM", is commercially available [12]. A fabric band is looped around the base of the tree trunk or a 
main branch, and adults become infected through direct contact with conidia on the fabric, which relies on chance.

Fungal infections can be transferred during mating: an infected beetle of a closely related species, A. glabripennis, can transfer an infection to its mating partner, particularly if the infected beetle is male $[7,13]$. In other Coleoptera, horizontal transmission has been reported in Psacothea hilaris [14] and Cylas formicarius [15]. Improving the infection rate would be a breakthrough in beetle control, especially as microbial insecticides are environmentally friendly and non-toxic to humans. Other studies that address the combination of attractant pheromones and entomopathogens in Coleoptera revealed effective transmission of the pathogen $[15,16]$.

The entire composition of the contact sex pheromone of $A$. malasiaca female was recently elucidated [17]. The surface of the female body is covered with contact sex pheromone, which is composed of three chemical groups: aliphatic hydrocarbons, ketones, and lactones [18-22]. When at least one component of each group was mixed together and presented to males, the males responded to the mixture in the same way as to crude female extract [18-20]. In our recent work, all synthetic pheromone blends elicited pheromonal activity to the same degree as did crude female extract [17]. During bioassays investigating pheromone candidates, we observed that males held strongly onto glass models of females and would not let go. This strong attachment gave us the idea to test a combination of entomopathogenic fungi and contact sex pheromone. If the contact pheromone has arrestant activity, it will increase the duration of contact and thus the rate of infection. Since the synthesis of the lactone components of the contact pheromone is complex, we used crude female extract to evaluate the activity. To develop a method for the practical control of this beetle, we tested whether the combination of "Biolisa Kamikiri SLIM" and contact pheromone improves the dose and spread of infection beyond the use of fungi alone.

\section{Materials and Methods}

\subsection{Insect Collection and Laboratory Rearing to Adults}

Anoplophora malasiaca adults were collected by hand from mandarin orange (Citrus unshiu Marc.) groves on Kunisaki Peninsula, Oita Prefecture, Japan, in mid-June 2016. Beetles were individually reared in clear plastic cups $(\sim 11 \mathrm{~cm}$ diameter $\times 9.5 \mathrm{~cm}$ height $)$ at $25{ }^{\circ} \mathrm{C}$ under a $15 \mathrm{~L}: 9 \mathrm{D}$ photoperiod, illuminated by fluorescent lamps. Each beetle was fed C. unshiu branches collected from the sampling sites. All cut branches were stored at $5{ }^{\circ} \mathrm{C}$ and used within 10 days. Eggs were obtained from 200 females collected in the field. Eggs laid on branches in the laboratory were collected and the hatched larvae were individually reared to adults on an artificial diet (Silkmate 2S, mulberry leaf-based diet; Nihon Nosan Kogyo, Yokohama, Japan). Emerged adults were individually held in clear plastic cups (as above). Adults started feeding on willow branches 1 week after emergence and were reared on willow for 3 weeks.

\subsection{Extraction of Female Contact Pheromone}

After 3 weeks of feeding, females were frozen and stored at $-30^{\circ} \mathrm{C}$. Because extracts of willow fed females were more attractive to A. malasiaca males than that of citrus-fed females, and mature female extract is more attractive than immature female extract [23], we used extract of 3-week-willow-fed-female for bioassay. The elytra of 10 females were removed and placed in $15 \mathrm{~mL}$ diethyl ether $(1.5 \mathrm{~mL} /$ female). After $5 \mathrm{~min}$ at room temperature, the extract was decanted. Elytra were rinsed twice with $15 \mathrm{~mL}$ ether, and the rinses were added to the extract. Ether was removed from the extracts under reduced pressure at $<30^{\circ} \mathrm{C}$, and the resulting residue (the "female extract") was dissolved in $200 \mu \mathrm{L}$ $n$-hexane and stored at $-30{ }^{\circ} \mathrm{C}$ until use. Solvents were distilled just before use.

\subsection{Recording Male Behavior to Evaluate Arrestant Activity of Female Extract}

Behavioral assays were conducted between $09: 00$ and $17: 00$ at $25^{\circ} \mathrm{C}(8 \mathrm{~h}$ recording, $4 \mathrm{~h}$ after lights on). A capsule-shaped black glass model (12 $\mathrm{mm}$ diameter $\times 35 \mathrm{~mm}$ length) 
was used as a female dummy [24]. It was affixed with a small piece of adhesive tape to the center of a filter paper disc ( $15 \mathrm{~cm}$ diameter, Toyo No. 2, Toyo Roshi Kaisha, Tokyo, Japan) and coated with female extract ( 1 female equivalent, fe), dissolved in ca. $20 \mu \mathrm{L}$ $n$-hexane. A male beetle was placed with a model coated with female extract or just solvent and covered with a clear plastic cup (as above). We tested 5 males separately at the same time (Figure $1 b, c)$. Male behavior was recorded every $10 \mathrm{~min}$ with a time-lapse camera. When a male was seen to be holding the model, the holding period was calculated as (no. of recorded of "holding" $\times 10$ ) min. The longest holding period was recorded. The sample sizes were 20 for female extract and 5 for solvent only.
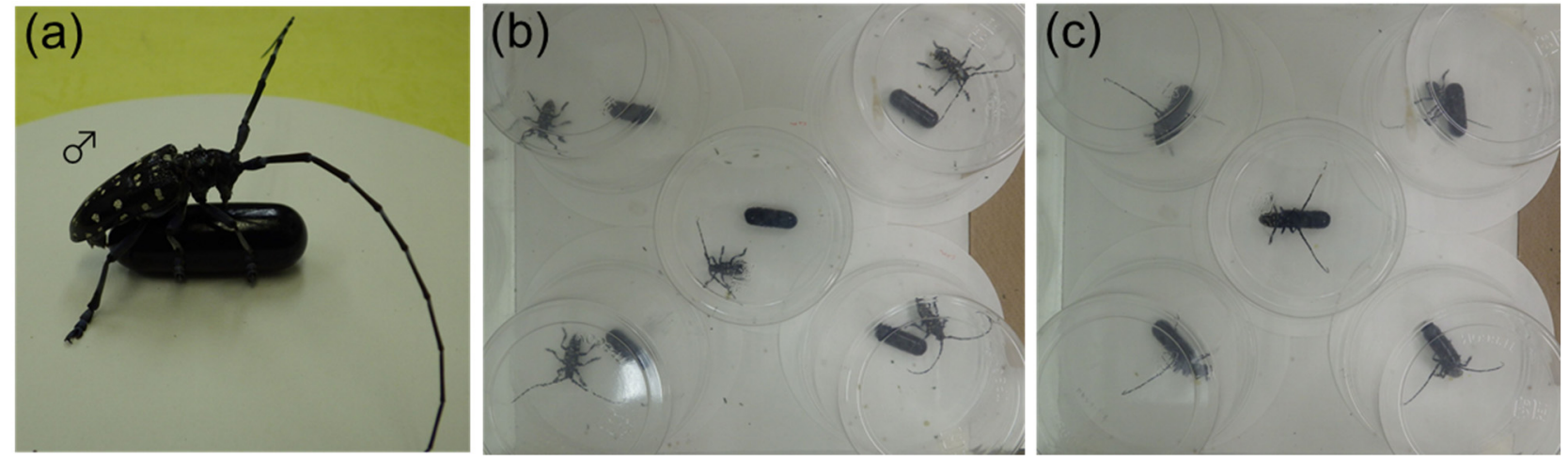

Figure 1. Anoplophora malasiaca males. (a) Male holding a glass model coated with female extract and bending his abdomen toward it. (b) Males with solvent-only glass models. All males ignored the models. (c) Males with models coated with female extract. Most males kept hold of the models.

\subsection{Conidial Adherence to Males}

"Biolisa Kamikiri SLIM" (Idemitsu Agri Co., Ltd. Tokyo, Japan) non-woven fabric ( $4 \mathrm{~mm}$ thick) was cut into pieces of $2.5 \mathrm{~cm} \times 5.0 \mathrm{~cm}$. A glass model coated with $1 \mathrm{fe}$ extract or solvent only was attached to its center and placed at the center of a plastic box $(30 \mathrm{~cm} \times$ $22 \mathrm{~cm} \times 6 \mathrm{~cm}$; Figure 1). A male was introduced near the model and left for $1 \mathrm{~h}$. Males were introduced near a glass model treated with solvent only (Male A, $n=9$, Figure 2 left) or treated with female extract (Male B, $n=10$, Figure 2 middle). The fabric size was larger than the model, so the male antennae and legs were encountered the fabric first. All males placed with coated glass models held the models and bend their abdomens toward them. After $1 \mathrm{~h}$, each male was ultrasonicated in $15 \mathrm{~mL}$ of $0.02 \%$ polyoxyethylene (20) sorbitan monopalmitate (Wako Pure Chemical Industry, Osaka, Japan, Tween 40, surfactant) in water for $2 \mathrm{~min}$, and the mean number of conidia in the solution (number of conidia $/ \mathrm{mm}^{3}$ ) were counted by hemocytometer under a microscope, then calculated the number of conidia released from the each male.

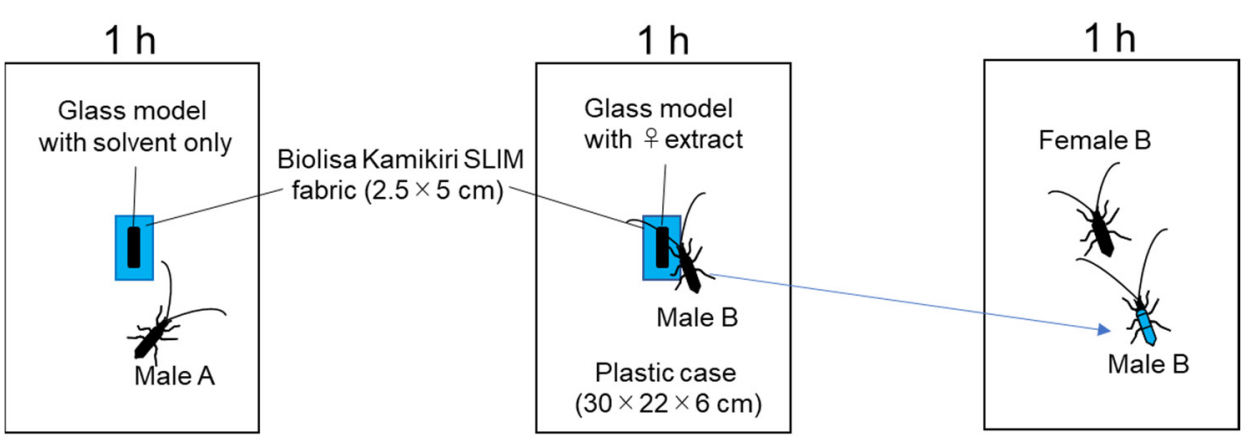

Figure 2. A male (A, B) was placed with a glass model on "Biolisa Kamikiri SLIM" fabric in a plastic box for $1 \mathrm{~h}$. Male B was placed with female B in another case for another $1 \mathrm{~h}$. 


\subsection{Conidial Adherence to Females That Copulated with Infected Males}

A male prepared as in Section 2.4 (Male B) was placed together with a female (Female $\mathrm{B}, n=10)$ in a plastic box $(30 \mathrm{~cm} \times 22 \mathrm{~cm} \times 6 \mathrm{~cm})$ for $1 \mathrm{~h}$ (Figure 2 right). All Male B were used only once. All males used in this assay held the female and bent their abdomen toward the female. After $1 \mathrm{~h}$, Female B was ultrasonicated as in Section 2.4, and conidia were counted.

\subsection{Statistical Analysis}

The calculated longest holding time ( $x$ min) was analyzed by Student's $t$-test at $p<0.01$. Individual conidial number $(y)$ was tested by one-way analysis of variance (ANOVA), and analyzed by Tukey's multiple comparison at $p<0.05$.

\section{Results}

\subsection{Arrestant Effect of Female Extract on Males}

When a glass model coated with female extract was presented to males, almost all males persistently tried to copulate with it (Figure 1a). During $8 \mathrm{~h}$ recording, males presented with an solvent only model walked around the floor and on the wall of the plastic cup (Figure 1b). However, most males presented with coated model held onto the model for a long time, and if they left it, they returned to it and held it again (Figure 1c).

Extract-coated glass models arrested males for an average of $5.1 \mathrm{~h}(307.5 \pm 36.5 \mathrm{~min}$; mean \pm SE, $n=20$ ) per 8-h experiment (Figure 3). Maximum arrested time was $8 \mathrm{~h}$ that equals to experiment period. On contrast, models without female extract only arrested males less than $0.3 \mathrm{~h}(16.0 \pm 4.0 \mathrm{~min}, n=5)$, arrested time was significantly different to that of female extract coated model (Student $t$-test, $p<0.01$ ).

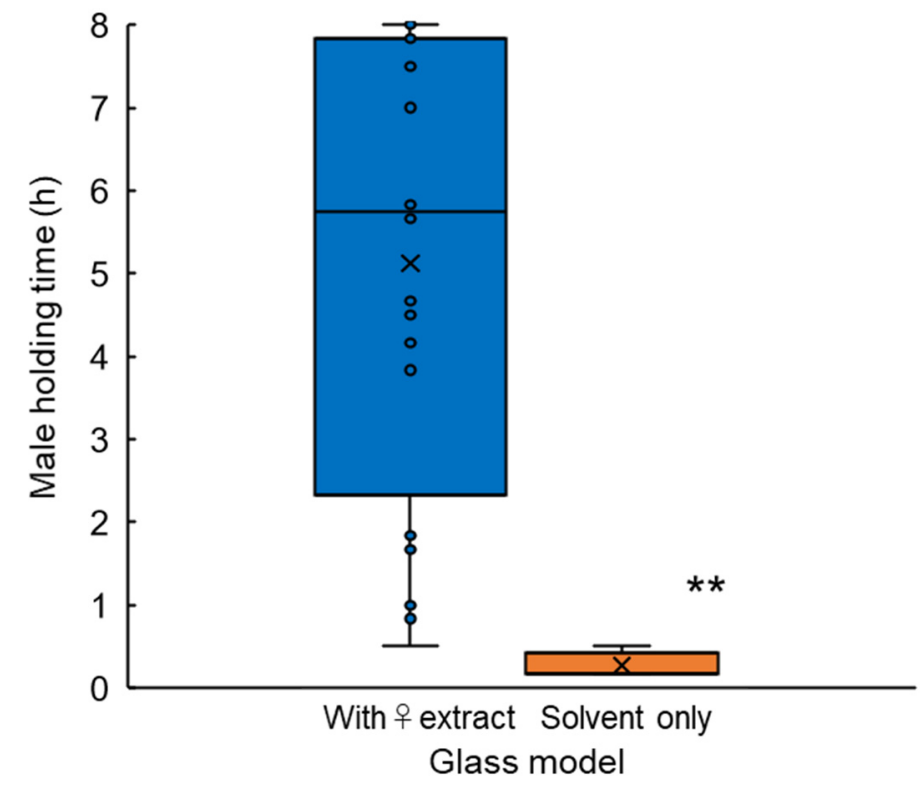

Figure 3. Male longest arrested time on a glass model coated with or without female extract during 8-h experiment. Box-plots: middle line, mean; boxes, quartiles; whiskers, maximum and minimum values. $\circ$ Data points; $\times$ average. ${ }^{* *}$ Significantly different at $p<0.01$ (Student's $t$-test).

\subsection{Conidial Adherence to Males with Help of Female Extract}

To evaluate the effect of the arrestant activity of female extract on infection by the fungus, we compared numbers of conidia on the body surface between males on models with and males on models without female extract on "Biolisa Kamikiri SLIM" fabric (Figure 2, left and center). Males presented with extract-coated models on "Biolisa Kamikiri SLIM" held the models without hesitation. These males acquired significantly more conidia $\left(370.2 \times 10^{5} \pm 104.4 \times 10^{5}\right.$, mean \pm SE; Figures 4 and 5 middle $)$ than those presented 
with uncoated models on "Biolisa Kamikiri SLIM" $\left(52.7 \times 10^{5} \pm 15.9 \times 10^{5}\right.$; Tukey's test, $p<0.05$; Figure 5 left). The mortality rates after $7 \mathrm{~d}$ were $50 \%$ with $3 \mathrm{~s}$ contact and $90 \%$ with 60 s contact ( $n=10$; Figure S1a, $\chi^{2}$-test, $p<0.06$ ), and was $80 \%$ and $100 \%$ after $9 \mathrm{~d}$.

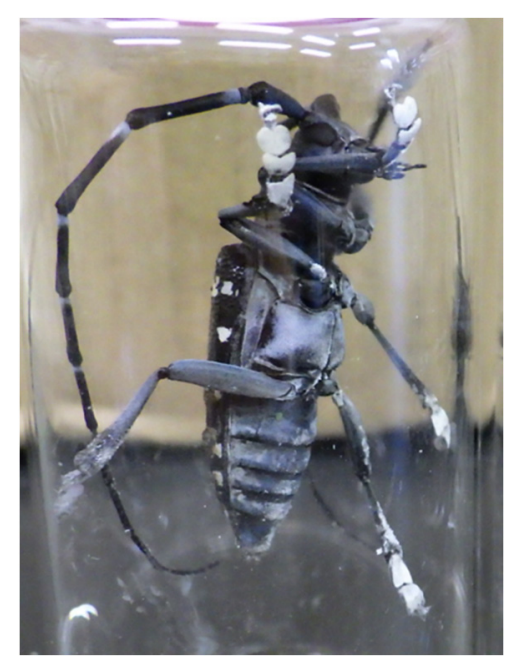

Figure 4. Anoplophora malasiaca male B after contact with "Biolisa Kamikiri SLIM" fabric. Foot pads and underside of abdomen are covered with white conidia.

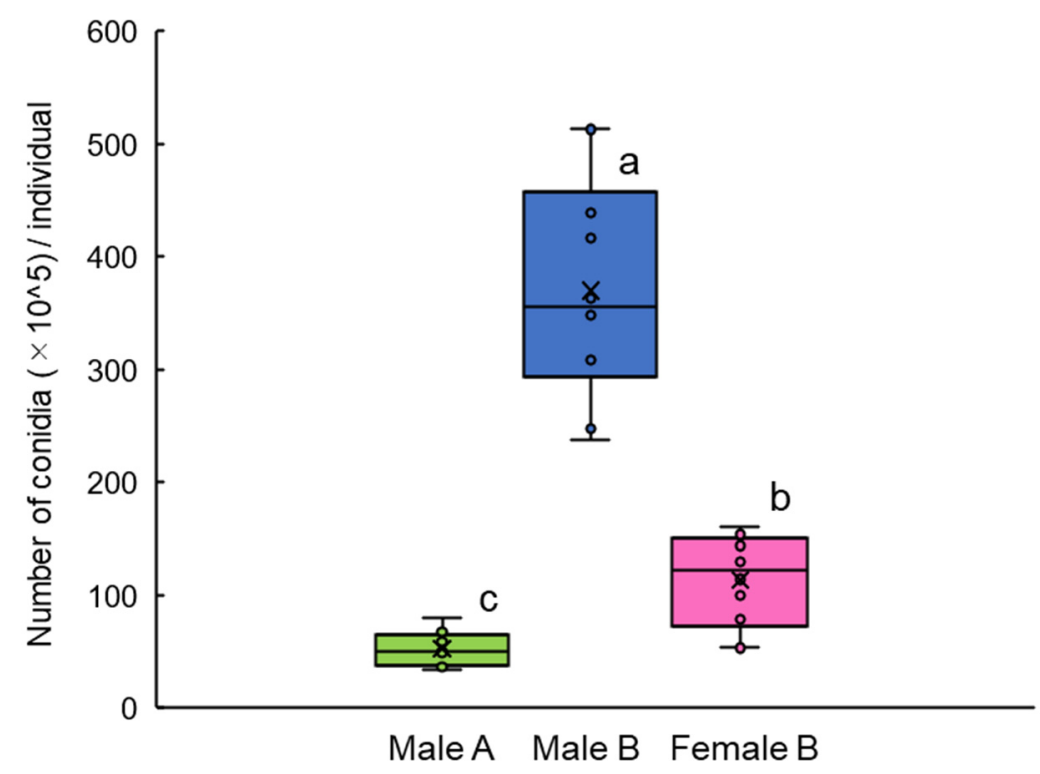

Figure 5. Numbers of conidia attached to adults' bodies. Male A: placed with a glass model without female extract on "Biolisa Kamikiri SLIM" fabric for $1 \mathrm{~h}$. Male B: placed with a glass model with female extract on "Biolisa Kamikiri SLIM" for $1 \mathrm{~h}$. Female B: placed with Male B for another $1 \mathrm{~h}$. Conidia were washed off in surfactant and counted. Box plots: middle line, mean; boxes, quartiles; maximum and minimum values, whiskers. $\circ$ Data points; $\times$ average. Different letters indicate significant differences (Tukey's test, $p<0.05$ ).

\subsection{Conidial Adherence to Live Females by Mating with Conidia Attached Males}

Males acquired conidia in the presence of female extract transferred significantly more conidia to females during mating (Female B, $113.7 \times 10^{5} \pm 41.3 \times 10^{5}$, Figure 5 right), than acquired by males in the absence of extract (Male A, $52.7 \times 10^{5} \pm 15.9 \times 10^{5}$; Tukey's test, $p<0.05$, Figure 5 left). The mortality of mated adults (both males exposed to "Biolisa Kamikiri SLIM" for $60 \mathrm{~s}$ and females that mated with them) after $7 \mathrm{~d}$ was 100\% (Figure S1b, 
$n=5 ; 5$ of 8 pairs mated). No unexposed males or females of 3 weeks' rearing died during the 9-day experiment.

\section{Discussion}

Contact sex pheromone of female $A$. malasiaca proved to have arrestant activity against conspecific males. The combination of entomopathogenic fungi and female contact sex pheromone improved both dose and spread of infection compared with fungi alone. A glass model coated with or without female extract was placed on fabric impregnated with conidia of entomopathogenic fungi and presented to males. Crude female extract on a black glass model greatly increased the male's exposure to the inoculated fabric, and, thus, the number of conidia picked up and later transferred to females during mating.

Our group previously showed that a capsule-shaped black glass model used as a female dummy and coated with female extract elicits mating behavior by males [24]. Models of other colors or of transparent glass are less attractive. Models without female extract do not elicit male mating behavior.

Bands of non-woven fabric or polyurethane impregnated with B. brongniartii conidia are looped around tree stems or branches $[9,25]$, where they infect adult beetles that walk over them, so they must be placed in positions where large numbers of adults pass through [26]. Anoplophora malasiaca generally oviposit at and emerged from the base of the host tree trunk, so if the bands are placed below the first branch, not only expecting laying egg female, all newly emerging adults should to be infected as they walk up the tree to feed [9]. The application of a conidial suspension to only abdomen, legs, or antennae of $A$. malasiaca led to high mortality [27]. The mortality of beetles that spent only 3 to $6 \mathrm{~s}$ walking on polyurethane foam impregnated with conidia of B. brongniartii for 3-6 s was $100 \%$ after 15 days [9]. Here, the mortality of beetles that walked on "Biolisa Kamikiri SLIM" for only $3 \mathrm{~s}$ was $50 \%$ and for $60 \mathrm{~s}$ was $90 \%$ after 7 days (Figure S1a), and was $80 \%$ and $100 \%$ after 9 days. When adult beetles of Capnodis tenebrionis were stimulated to climb non-woven commercial fiber bands impregnated with Metarhizium anisopliae conidia, no significant correlation was detected between the time needed to cross the band and time of death; total mortality rates were $85.7 \%$ to $100.0 \%$ [10]. In A. malasiaca, in contrast, the frequency of touching bands impregnated with $B$. brongniartii conidia might be improved for greater mortality in the field [27]. Here, mortality increased with longer exposure to the fabric, supporting the use of the fabric band in combination with female contact pheromone to enhance infection of this species. No unexposed males or females died during the 9-day experiment. These results and previous reports show that it would be worthwhile for practical control of $A$. malasiaca to improve the frequency of contact with contaminated fabric.

Our results show that the contact pheromone kept the males in contact with the "Biolisa Kamikiri SLIM" fabric for longer, increasing the number of fungal conidia on them (Figure 5). Rather than continuously holding the coated glass models, the males sometimes released the models, walked around them, and held them again. This possible femaleguarding behavior thus increases the chance of picking up conidia. Later contact of these infected males with females thus infects the females. Sexual transmission of B. brongniartii by mating of the yellow spotted longicorn beetle P. hilaris has been reported [14]. So even if females do not come into contact with the "Biolisa Kamikiri SLIM", they have a chance of infection through mating. At $7 \mathrm{~d}$ after mating with males that spent $60 \mathrm{~s}$ in contact with conidia, female mortality was $100 \%$ (Figure S1b). This means that conidia on male bodies were successfully transferred to females during mating, and that dose enough to kill her. Thus, contact pheromone might improve the infection rate in the field. One practical use of Biolisa Kamikiri SLIM with a contact pheromone is a fabric band on which 1 or 2 glass models coated with female extract (or, in future, synthetic pheromone blend), looped around the base of the trunk, as is used already.

The effectiveness of entomopathogens as biopesticides can be enhanced by their use in combination with chemical control methods. When used together, M. brunneum and 
the insecticide imidacloprid synergistically reduced survival time of $A$. glabripennis adults relative to either alone [28]. However, the rate of sporulation of the fungus was reduced.

Many cerambycid beetles are known to have a contact pheromone [29-37]. If these pheromones have arrestant activity, they could be used to increase the duration of contact with entomopathogenic fungi. This strategy might be applied to other important pest beetles.

A volatile pheromone-based attract-and-kill strategy might be made possible by using bait stations containing an attractant along with either a toxicant or an entomopathogen $[7,15,16,25]$. Sex pheromones have been used as beetle attractants; a sex pheromone trap made with a bottle with exit holes containing conidia of B. bassiana was designed and tested to control the sweet potato weevil, Cylas formicarius [15]. The use synthetic female sex pheromone was effective for the transmission of $M$. brunneum by male Agriotes obscurus click beetles [16]. An attract-and-kill strategy against $A$. malasiaca is not yet realistic because no effective volatile pheromone nor attractant has yet been formulated. Several reports describe the use of chemicals derived from host plants or male volatiles to attract A. malasiaca over short distances [38-40]. A blend of sesquiterpenes derived from a host plant C. unshiu attracted adults in the field, although they landed not on but near lures which impregnated with the blend [38]. This would increase the opportunity for infection if the microbial fabric were set near the lures.

However, once an effective attractant is developed, beetles will be attracted to the fungal bands and become infected. In combination with a contact pheromone, attractdelay-kill strategy could achieve control of $A$. malasiaca.

\section{Conclusions}

Female contact pheromone of $A$. malasiaca arrested conspecific males. In combination with a black glass model coated with female extract and fabric impregnated with conidia of an entomopathogenic fungus, it increased the number of conidia on male bodies and thus mortality. Infected males transferred conidia to the females during mating. This combination could be used to develop a method for the effective control of this beetle.

Supplementary Materials: The following are available online at https:/ /www.mdpi.com/article/10 .3390 /insects12050383/s1, Figure S1. Mortality of A. malasiaca adults $7 \mathrm{~d}$ after contact with "Biolisa Kamikiri SLIM". (a) Adult mortality following 3 or $60 \mathrm{~s}$ contact (each $n=10$, virgin adults, $\chi^{2}$-test, $p<0.06$ ). (b) Mortality of mated adults. "60 sec/mated o": : males exposed to "Biolisa Kamikiri SLIM" for $60 \mathrm{~s}$ and then mated with females. "mated $\%$ ": females that mated with males exposed to "Biolisa Kamikiri SLIM" for $60 \mathrm{~s}$ just before mating ( $n=5,5$ of 8 pairs mated).

Author Contributions: Conceptualization, N.F.-T. and H.Y.; methodology, N.F.-T.; validation, N.F.-T. and H.Y.; formal analysis, N.F.-T.; investigation, N.F.-T. and H.Y.; writing-original draft preparation, N.F.-T.; writing-review and editing, H.Y. Both authors have read and agreed to the published version of the manuscript.

Funding: This research was partially supported by a Grant-in-Aid for Scientific Research (C) (17K07686) and a Grant-in-Aid for Challenging Exploratory Research (16K14867) from the Ministry of Education, Culture, Sports, Science, and Technology, Japan.

Institutional Review Board Statement: Not applicable.

Acknowledgments: We thank Yuta Goto of Oita Prefectural Fruit Tree Research Institute for providing the citrus twigs, Takashi Noda of Japan Plant Protection Association and Masahiko Tokoro of Forestry and Forest Products Research Institute for collecting the insects. We also thank Ikuko Hashimoto and Masako Higuchi of NARO for insect rearing.

Conflicts of Interest: The authors declare no conflict of interest. 


\section{References}

1. Sjöman, H.; Östberg, J.; Nilsson, J. Review of host trees for wood-boring pests Anoplophora glabripennis and Anoplophora chinensis: An urban forest perspective. Arboric. Urban. For. 2014, 40, 143-164.

2. Kojima, K.; Nakamura, S. Food Plants of Cerambycid Beetles (Cerambydae, Coleoptera) in Japan; Hiba Society of Natural History Press: Hiroshima, Japan, 1986; pp. 128-133.

3. Ohbayashi, N. Genus Anoplophora Hope, 1839. In An Illustrated Guide to Identification of Longicorn Beetles of Japan; Ohbayashi, N., Satô, M., Kojima, K., Eds.; Tokai University Press: Tokyo, Japan, 1992; pp. 583-584.

4. Clifton, E.H.; Jaronski, S.T.; Hajek, A.E. Virulence of commercialized fungal entomopathogens against Asian longhorned beetle (Coleoptera: Cerambycidae). J. Insect Sci. 2020, 20, 1-6. [CrossRef]

5. Goble, T.A.; Hajek, A.E.; Jackson, M.A.; Gardescu, S. Microsclerotia of Metarhizium brunneum F52 applied in hydromulch for control of Asian longhorned beetles (Coleoptera: Cerambycidae). J. Econ. Entomol. 2015, 108, 433-443. [CrossRef] [PubMed]

6. Goble, T.A.; Rehner, S.A.; Long, S.J.; Gardescu, S.; Hajek, A.E. Comparing virulence of North American Beauveria brongniartii and commercial pathogenic fungi against Asian longhorned beetles. Biol. Control 2014, 72, 7291-7297. [CrossRef]

7. Hajek, A.E.; Bauer, L.S. Use of entomopathogens against invasive wood boring beetles in North America. In Use of Microbes for Control and Eradication of Invasive Arthropods; Hajek, A.E., Glare, T.R., O'Callaghan, M.O., Eds.; Springer: Dordrecht, The Netherlands, 2009; pp. 159-179. [CrossRef]

8. Tsutsumi, T. Microbial control of longicorn beetles using non-woven fabric sheet containing Beauveria brongniartii in the orchard. Proc. Soc. Invertebr. Pathol. Sapporo Jpn. 1998, 203-209.

9. Tsutsumi, T.; Kashio, T.; Hashimoto, S.; Gyoutoku, Y.; Kai, I.; Narahara, M. Studies on biological control of white spotted longicorn beetles, Anoplophora malasiaca by an entmogenous fungus, Beauveria brongniartii. IV. Field evaluation of hanging polyurethane foam sheet containing B. brongniartii conidia on citrus trees for the control of adult beetles. Proc. Ass. Plant. Prot. Kyushu 1990, 36, 173-176.

10. Marannino, P.; Cándido, S.Á.; de Lillo, E.; Quesada-Moraga, E. Evaluation of Metarhizium anisopliae (Metsch) Sorok. to target larvae and adults of Capnodis tenebrionis (L.) (Coleoptera: Buprestidae) in soil and fiber band applications. J. Invertebr. Pathol. 2008, 97, 237-244. [CrossRef] [PubMed]

11. Lacey, L.A.; Grzywacz, D.; Shapiro-Ilan, D.I.; Frutos, R.; Brownbridge, M.; Goettel, M.S. Insect pathogens as biological control agents: Back to the future. J. Invertebr. Pathol. 2015, 132, 1-41. [CrossRef]

12. Higuchi, T.; Saika, T.; Senda, S.; Mizobata, T.; Kawata, Y.; Nagai, J. Development of biorational pest control formation against longicorn beetles using a fungus, Beauveria brongniartii (Sacc.). Petch. J. Ferment. Bioeng. 1997, 84, 236-243. [CrossRef]

13. Peng, F.; Gardescu, S.; Hajek, A.E. Transmission of Metarhisium brunneum conidia between male and female Anoplophora grabripennis adults. BioControl 2011, 56, 771-780. [CrossRef]

14. Tsutsumi, T.; Yamanaka, M. Sexual transmission of entomogeneous fungus, Beauveria brongniartii GSES, between yellow spotted longicorn beetle Psacothea hilaris adults by mating behavior. Jpn. J. Appl. Entomol. Zool. 1995, 39, 267-269. [CrossRef]

15. Yasuda, K. Auto-infection system for the sweet potato weevil, Cylas Formicarius (Fabricius) (Coleoptera: Curculionidae) with entomopathogenic fungi, Beauveria bassiana using a modified sex pheromone trap in the field. Appl. Entomol. Zool. 1999, 34, 501-505. [CrossRef]

16. Leung, J.P.S.; Janmaat, A.F.; Kabaluk, J.T.; Cory, J.S. The effect of synthetic female sex pheromone on the transmission of the fungus Metarhizium brunneum by male Agriotes obscurus click beetles. J. Invert. Pathol. 2021, 179, 107534. [CrossRef]

17. Fujiwara-Tsujii, N.; Yasui, H.; Yasuda, T.; Wakamura, S.; Akino, T.; Fukaya, M.; Suzuki, T.; Hoshi, T.; Hagiwara, H.; Ono, H. Contact sex pheromone activity of synthetic Gomadalactones in male white-spotted longhorn beetle, Anoplophora malasiaca (Coleoptera: Cerambycidae). J. Chem. Ecol. 2019, 45, 440-446. [CrossRef]

18. Fukaya, M.; Akino, T.; Yasuda, T.; Wakamura, S.; Satoda, S.; Senda, S. Hydrocarbon components in contact sex pheromone of the white-spotted longicorn beetle, Anoplophora malasiaca (Thomson) (Coleoptera: Cerambycidae) and pheromonal activity of synthetic hydrocarbons. Entomol. Sci. 2000, 3, 211-218.

19. Yasui, H.; Akino, T.; Yasuda, T.; Fukaya, M.; Ono, H.; Wakamura, S. Ketone components in contact sex pheromone of the white-spotted longicorn beetle, Anoplophora malasiaca, and pheromonal activity of synthetic ketones. Entomol. Exp. Appl. 2003, 107, 167-176. [CrossRef]

20. Yasui, H.; Akino, T.; Yasuda, T.; Fukaya, M.; Wakamura, S.; Ono, H. Gomadalactones A, B, and C: Novel 3-oxabicyclo[3.3.0]octane compounds in the contact sex pheromone of the white-spotted longicorn beetle, Anoplophora malasiaca. Tetrahedron Lett. 2007, 48, 2395-2400. [CrossRef]

21. Mori, K. Absolute configuration of gomadalactones A, B and C, the components of the contact sex pheromone of Anoplophora malasiaca. Tetrahedron Lett. 2007, 48, 5609-5611. [CrossRef]

22. Suzuki, T.; Hagiwara, H.; Uchida, H.; Tsujii, N.; Ono, H. Japan Patent JP2017-095381. 2017. Available online: https: / / astamuse. com/ja/published/JP/No/2017095381 (accessed on 1 June 2007).

23. Fujiwara-Tsujii, N.; Yasui, H.; Wakamura, S. Population differences in male responses to chemical mating cues in the white-spotted longicorn beetle, Anoplophora malasiaca. Chemoecology 2013, 23, 113-120. [CrossRef]

24. Fukaya, M.; Akino, T.; Yasuda, T.; Yasui, H.; Wakamura, S. Visual and olfactory cues for mate orientation behaviour in male white-spotted longicorn beetle, Anoplophora malasiaca. Entomol. Exp. Appl. 2004, 111, 111-115. [CrossRef] 
25. Brabbs, T.; Collins, D.; Hérard, F.; Maspero, M.; Eyre, D. Prospects for the use of biological control agents against Anoplophora in Europe. Pest. Manag. Sci. 2015, 71, 7-14. [CrossRef] [PubMed]

26. Adachi, I.; Korenaga, R.; Arai, T. Movement patterns of Anoplophora malasiaca (Thomson) (Coleoptera: Cerambycidae) adults within a citrus tree. Bull. Fruit Tree Res. Stn. 1992, 23, 179-191.

27. Hashimoto, S.; Kashio, T.; Tsutsumi, T.; Gyoutoku, Y.; Kai, I. Probability for biological control of whitespotted Longicorn Beetle, Anoplophora malasiaca by an Entmogenous Fungus, Beauveria brongniartii. Plant Prot. 1992, 46, 66-70.

28. Russel, C.W.; Ugine, T.A.; Hajek, A.E. Interactions between imidacloprid and Metarhizium brunneum on adult Asian longhorened beetles (Anoplophora glabripennis (Motschulsky) (Coleoptera: Cerambycidae). J. Invertebr. Pathol. 2010, 105, 305-311. [CrossRef]

29. Millar, J.G.; Hanks, L.M. Chemical Ecology of Cerambycids. In Cerambycidae of the World; Wang, Q., Ed.; CRC Press: Boca Raton, FL, USA, 2017; pp. 161-208.

30. Fukaya, M.; Yasuda, T.; Wakamura, S.; Honda, H. Reproductive biology of the yellow-spotted longicorn beetle, Psacothea hilaris (Pascoe) (Coleoptera: Cerambycidae). III. Identification of contact sex pheromone on female body surface. J. Chem. Ecol. 1996, 22, 259-270. [CrossRef] [PubMed]

31. Barbour, J.D.; Lacey, E.S.; Hanks, L.M. Cuticular hydrocarbons mediate mate recognition in a species of longhorned beetle (Coleoptera: Cerambycidae) of the primitive subfamily Prioninae. Ann. Entomol. Soc. Am. 2007, 100, 333-338. [CrossRef]

32. Zhang, A.; Oliver, J.E.; Chauhan, K.; Zhao, B.; Xia, L.; Xu, Z. Evidence for contact sex recognition pheromone of the Asian longhorned beetle, Anoplophora glabripennis (Coleoptera: Cerambycidae). Naturwissenschaften 2003, 90, 410-413. [CrossRef]

33. Ginzel, M.D.; Millar, J.G.; Hanks, L.M. (Z)-9-Pentacosene-contact sex pheromone of the locust borer, Megacyllene robiniae. Chemoecology 2003, 13, 135-141. [CrossRef]

34. Ginzel, M.D.; Moreira, J.A.; Ray, A.M.; Millar, J.G.; Hanks, L.M. (Z)-9-Nonacosene-major component of the contact sex pheromone of the beetle Megacyllene caryae. J. Chem. Ecol. 2006, 32, 435-451. [CrossRef]

35. Hughes, G.P.; Bello, J.E.; Millar, J.G.; Ginzel, M.D. Determination of the absolute configuration of female-produced contact sex pheromone components of the longhorned beetle, Neoclytus acuminatus acuminatus (F.) (Coleoptera: Cerambycidae). J. Chem. Ecol. 2015, 41, 1050-1057. [CrossRef] [PubMed]

36. Rutledge, C.E.; Millar, J.G.; Romero, C.M.; Hanks, L.M. Identification of an important component of the contact sex pheromone of Callidiellum rufipenne (Coleoptera: Cerambycidae). Environ. Entomol. 2009, 38, 1267-1275. [CrossRef] [PubMed]

37. Silk, P.J.; Sweeney, J.; Wu, J.; Sopow, S.; Mayo, P.D.; Magee, D. Contact sex pheromones identified for two species of longhorned beetles (Coleoptera: Cerambycidae) Tetropium fuscum and T. cinnamopterum in the subfamily Spondylidinae. Environ. Entomol. 2011, 40, 714-726. [CrossRef] [PubMed]

38. Yasui, H.; Yasuda, T.; Fukaya, M.; Akino, T.; Wakamura, S.; Hirai, Y.; Kawasaki, K.; Ono, H.; Narahara, M.; Kousa, K.; et al. Host plant chemicals serve intraspecific communication in the white-spotted longicorn beetle, Anoplophora malasiaca (Thomson) (Coleoptera: Cerambycidae). Appl. Entomol. Zool. 2007, 42, 255-268. [CrossRef]

39. Yasui, H.; Akino, T.; Fukaya, M.; Wakamura, S.; Ono, H. Sesquiterpene hydrocarbons: Kairomones with a releaser effect in the sexual communication of the white-spotted longicorn beetle, Anoplophora malasiaca (Thomson) (Coleoptera: Cerambycidae). Chemoecology 2008, 18, 233-242. [CrossRef]

40. Yasui, H.; Fujiwara-Tsujii, N.; Yasuda, T. Detection of volatile pheromone candidates from the white-spotted longicorn beetle, Anoplophora malasiaca (Coleoptera: Cerambycidae). Appl. Entomol. Zool. 2019, 54, 203-211. [CrossRef] 